\title{
クロメートフリー化成処理鋼板の開発動向と今後の展望
}

\author{
松田武士 ${ }^{\mathrm{a}}$, 松崎晃 ${ }^{\mathrm{a}}$, 平 章一郎 ${ }^{\mathrm{a}}$
}

a JFE スチール(株) ( ₹ 260-0835千葉県千葉市中央区川崎町 1)

\section{Recent and Future Trend of Chromate-free Coated Steel Sheets}

Takeshi MATSUDA ${ }^{\mathrm{a}}$, Akira MATSUZAKI ${ }^{\mathrm{a}}$ and Shoichiro TAIRA ${ }^{\mathrm{a}}$

${ }^{\mathrm{a}}$ JFE Steel Corporation (1 Kawasaki-cho, Chuo-ku, Chiba-shi, Chiba 260-0835)

Keywords : Chromate-Free, Galvanized Steel Sheet, Corrosion Resistance, Conductivity, Self-Healing

\section{1.はじめに}

亜鉛めっき鋼板は下地の鋼板よりも亜鉛めっきが優先して 腐食する犠牲防食作用を有する。さらに亜鉛の腐食生成物に よって鋼板の腐食速度が低下するため ${ }^{1)}$, 自動車, 電機, 建 材用途などの多岐に渡る防錆鋼板として使用されている。ま た, 白物家電や $\mathrm{OA}, \mathrm{AV}$ 機器などの筐体に用いられている 亜鉛めっき鋼板は美麗な外観が求められるため, 亜鉛めっき 自身の腐食によって発生する白錆も抑制する必要がある。そ のため, 覀鉛めっき上に六価クロムによる化成処理を行った クロメート皮膜が適用され, クロメート化成処理鋼板として 商品化された ${ }^{2)}$ 。このクロメート皮膜は優れたバリア性, 密 着性と自己補修性を有するため, 薄膜でも優れた耐食性を発 現する ${ }^{3)}$ 。そのため, (1)皮膜コストが安価, (2)覀鉛めっき鋼 板本来の外観や性能を損なわない，(3添加物により耐指紋性, 塗装性，加工性などの高機能化が可能などの特徴を有する。

一方, 20 世紀後半以降, 環境保全に対する意識が世界的 に広まり, 1992 年の地球環境サミットでは地球規模での環

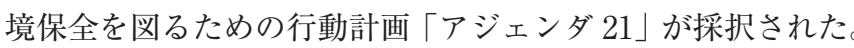
電気電子機器に関しては, 2003 年にRoHS (Restriction of Hazardous Substances) 指令が公布され，2006 年以降の六価ク ロム使用が禁止され, クロメート化成処理鋼板のクロメート フリー化が急務となった。クロメート皮膜の優れたバリア性, 密着性と自己補修性を実現するため, 様々な代替皮膜の研究 開発が行われ，国内鉄鋼メーカー各社は世界に先駆けてクロ メートフリー化成処理鋼板の商品化を実現し, 2000 年代前 半までに置き換えが完了した ${ }^{4)} 。 2000$ 年代半ば以降，家電 製品のデジタル化や高機能化が進展し, 海外鉄鋼メーカーで もクロメートフリー化成処理鋼板が商品化され, 機能やコス トの面での競争が激化したため, 高機能化, 低コスト化を追 求したクロメートフリー化成処理鋼板が開発され, 現在に 至っている ${ }^{5), 6)}$

また， RoHS 指令などの製品環境規制と並行して，製品の ライフサイクル（資源採取一原料生産一製品生産一流通・消 費一廃棄・リサイクル) 全体における環境負荷を評価する考
え (LCA : Life Cycle Assessment)が世界的に浸透しつつある。 LCA における環境負荷を低減させる一つの手法として, 消 費期間における製品の最終寿命 (EoL : End of Life)を長期化 させることが挙げられる。化成処理が施された亜鉛めっき鋼 板の場合, めっき厚や化成皮膜厚を厚くすることで耐食性を 高めることが出来るが，亜鉛や皮膜成分の消費量が増大する ためLCAの観点から好ましくない。一方, 高分子材料の分 野においてもEoL を長期化させるための研究開発が行われ ており，エポキシ樹脂中に補修剂を内包したマイクロカプセ ルを分散させた複合高分子材料が開発され，外部から欠陥が 導入された場合にマイクロカプセルが崩壊し, 溶出した補修 剂が久陥部を修復すると報告されている ${ }^{7)}$ 。この研究が Nature 誌に取り上げられると, 防錆剂をマイクロカプセルな どのキャリアーに内包させて皮膜中に分散したオンデマンド 防錆皮膜が提唱された。このオンデマンド防錆皮膜は物理的 または化学的な変化が生じた場合のみキャリアー中の防錆剂 が放出されるため, 亜鉛めっき鋼板のみならず, 各種金属板 の EoL 長期化を目指した研究開発が進められている。

本報では 2000 年代前半までに開発されたものを「第一世 代クロメートフリー皮膜」, 2000 年代半ば以降に開発された ものを「第二世代クロメートフリー皮膜」として分類し，そ れぞれの研究開発例を紹介する。さらにオンデマンド防錆皮 膜を「次世代クロメートフリー皮膜」と称し, クロメートフ リー皮膜の今後の展望として研究開発例を紹介する。

\section{2.クロメート皮膜の特徵と役割}

クロム酸を亜鉛めっき鋼板に塗布することで, 以下の反応 式によって三価の水和酸化クロムが形成される。

$$
\begin{aligned}
\text { アノード反応 }: & \mathrm{Zn} \rightarrow \mathrm{Zn}^{2+}+2 \mathrm{e}^{-} \\
\text {カソード反応 }: & \mathrm{HCr}_{2} \mathrm{O}_{7}{ }^{-}+7 \mathrm{H}^{+}+6 \mathrm{e}^{-} \rightarrow 2 \mathrm{Cr}(\mathrm{OH})_{3}+\mathrm{H}_{2} \mathrm{O} \\
& \text { または } \\
& \mathrm{CrO}_{4}{ }^{2-}+4 \mathrm{H}_{2} \mathrm{O}+3 \mathrm{e}^{-} \rightarrow \mathrm{Cr}(\mathrm{OH})_{3}+5 \mathrm{OH}^{-}
\end{aligned}
$$

クロメート皮膜は水和酸化クロムが加熱乾燥されることで オール架橋 (Cr-OH-) もしくはオキソ架橋 (Cr-O-) を有する高 分子皮膜として亜鉛めっき上に形成され(図1), めっき界面 
腐食因子

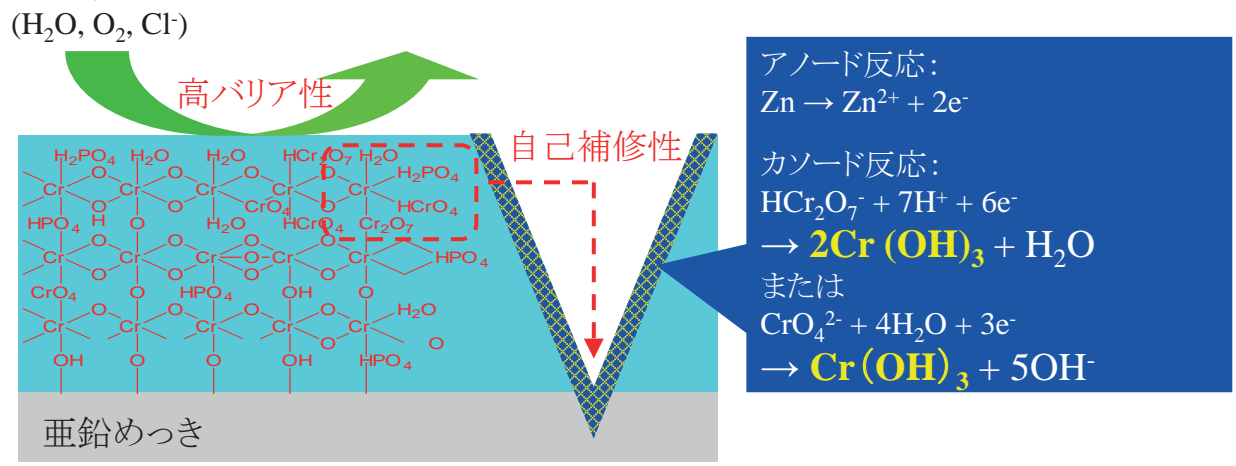

図 1 クロメート皮膜の防錆機構

とも化学結合するため, $\mathrm{H}_{2} \mathrm{O}, \mathrm{O}_{2}$ や $\mathrm{Cl}^{-}$などの腐食因子に対 するバリア性や亜鉛めっきとの密着性に優れている。また, 皮膜が損傷を受けた場合, 皮膜中に含まれる六価クロムの酸 化反応により不動態皮膜が形成され，還元された三価クロム が水和酸化物を形成する自己補修性を有する ${ }^{3)}$ 。これら独特 の防錆機構により, クロメート皮膜は薄膜でも優れた耐食性 を発現することが知られている ${ }^{8)}$ 。そのため, 皮膜コストが 安価であり，溶接性などの亜鉛めっき鋼板本来の性能を損な うことがなく, 電気亜鉛めっき鋼板や溶融亜鉛めっき鋼板の みならず，アルミニウム板などの防錆皮膜としても適用され ている。また，クロメート皮膜中やその上層に耐指紋性，塗 装性, 加工性などの機能を有する皮膜成分を加えることで高 機能化が可能となるため, 1990 年代前半までに高機能クロ メート化成処理鋼板として広く普及した ${ }^{2)}$ 。

\section{3. 第一世代クロメートフリー皮膜の開発動向}

クロメート皮膜は三価の水和酸化クロムの加熱乾燥によっ て得られる高分子皮膜のバリア性と密着性に加え, 六価クロ ムの自己補修性によって優れた耐食性を発現する。従って, 第一世代クロメートフリー皮膜の設計指針としては, 有機系 皮膜成分によりバリア性と密着性を担保し，無機系皮膜成分 により自己補修性を付与するものが多く, それらを複合化し

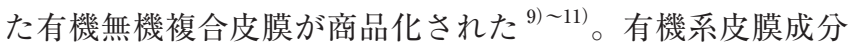
としては，エチレン系，エポキシ系，ウレタン系樹脂，多価 $\mathrm{OH}$ 基を含有する樹脂またはキレート剤を用いたクロメート フリー皮膜が報告されている ${ }^{5)}$ 。例えば, 吉見らはエポキシ 樹脂, アミン変性エポキシ樹脂, ウレタン樹脂, エチレン樹 脂，アクリル樹脂の酸素透過性と，これら樹脂を亜鉛めっき 鋼板上に成膜した際の耐食性を評価し，酸素に対する樹脂の バリア性と耐食性に相関があることを明らかにした ${ }^{11)}$ 。無 機系皮膜成分としては, Cr と同じ VI 族に属する Mo などの 遷移金属オキソアニオン, $\mathrm{Ti}, \mathrm{V}, \mathrm{Mn}$ などの遷移金属, La, Ce などの希土類元素, リン酸などの無機酸を用いたクロメー トフリー皮膜が報告されている ${ }^{5)}$ 。例えば，荒牧らは亜鉛板 上に $\mathrm{Ce}_{2} \mathrm{O}_{3} / \mathrm{Ce}\left(\mathrm{NO}_{3}\right)_{3}$ 皮膜を成膜させ，皮膜に欠陥が生じた 際に $\mathrm{Ce}\left(\mathrm{NO}_{3}\right)_{3}$ から生じた $\mathrm{Ce}^{3+}$ より欠陷内部に $\mathrm{Ce}_{2} \mathrm{O}_{3}$ が生成 し，自己補修作用を示すことを報告している ${ }^{12)}$ 。鈴木らは, 亜鉛めっき鋼板上にポリウレタン樹脂とリン酸から成る皮膜 を成膜させることで皮膜欠陥部の腐食が抑制されることを明
らかにし，腐食試験後の欠陥部に Zn と P から成る生成物を 確認し, 皮膜中のリン酸成分が自己補修性を示すと報告して いる ${ }^{13)}$ 。また, 野呂らはリン酸と亜鉛めっきの溶解反応に よって，エポキシ樹脂皮膜中や亜鉛めっき界面に難溶性リン 酸覀鉛化合物が生成し，皮膜のバリア性，密着性と自己補修 性の発現に寄与している報告しており ${ }^{14)}$ ，有機樹脂とリン 酸の複合皮膜は第一世代クロメートフリー皮膜として広く適 用されている。

一方，難溶性リン酸亜鉛の形成には亜鉛めっきの溶解が伴 うため, 特に電気亜鉛めっき鋼板を用いた場合, 六方晶に起 因するめっき凸部の溶解が顕著となり，導電性が低下するこ とが報告されている(図 2 (a) ) ${ }^{15)}$ 。また, バリア性と密着性 を担う有機系皮膜成分の電気抵抗は概ね $10^{9} \Omega \mathrm{m}$ 以上である ため, 皮膜厚が厚くなると亜鉛めっき鋼板の導電性(電気抵 抗 $6 \times 10^{-8} \Omega \mathrm{m}$ ) が失われ溶接性などが低下する(図 $\left.2(\mathrm{~b})\right)$ 。 従って, 第一世代クロメートフリー皮膜は皮膜厚の適正化に より耐食性と導電性の適度な両立を成し得ていたが, そのレ ベルには限界があった。

\section{4. 第二世代クロメートフリー皮膜の開発動向}

2000 年代後半になると, 家電製品の新興国への市場拡大 に伴い海外材との競合が激化し, クロメートフリー化成処理 鋼板の高機能化や多機能化によるコスト低減が求められた。 例えば, $\mathrm{AV} \cdot \mathrm{OA}$ 機器では電磁波漏洩防止のためにシールド ボックスが設けられているが，化成処理鋼板の導電性が不十 分な場合, ボックスを構成する蓋と箱との接合部にて電磁波

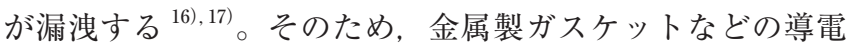
性材料を介して接合されているが, 家電メーカーでは製品の コストアップに繋がるため, 優れた導電性を有する高機能化 成処理鋼板が求められていた。また，加工メーカーでの塗装 工程省略のため化成処理のままでも使用できる高耐食化成処 理鋼板, 塗油・脱脂工程省略のため塗油なしでもプレス可能 な高潤滑化成処理鋼板が開発されている。更に加工メーカー では製造コスト低減や環境負荷物質削減のため, 従来の溶剤 系後塗装から粉体塗装への切り替えが進んでおり，粉体塗装 の後塗装密着性を重視した化成処理鋼板も開発されている。 しかし，鉄鋼メーカーでは少量多品種の生産となり量産効果 が得られないため, 高耐食性, 高潤滑性及び後塗装密着性も 付与した多機能化成処理鋼板が求められていた。また，車載 
(a)

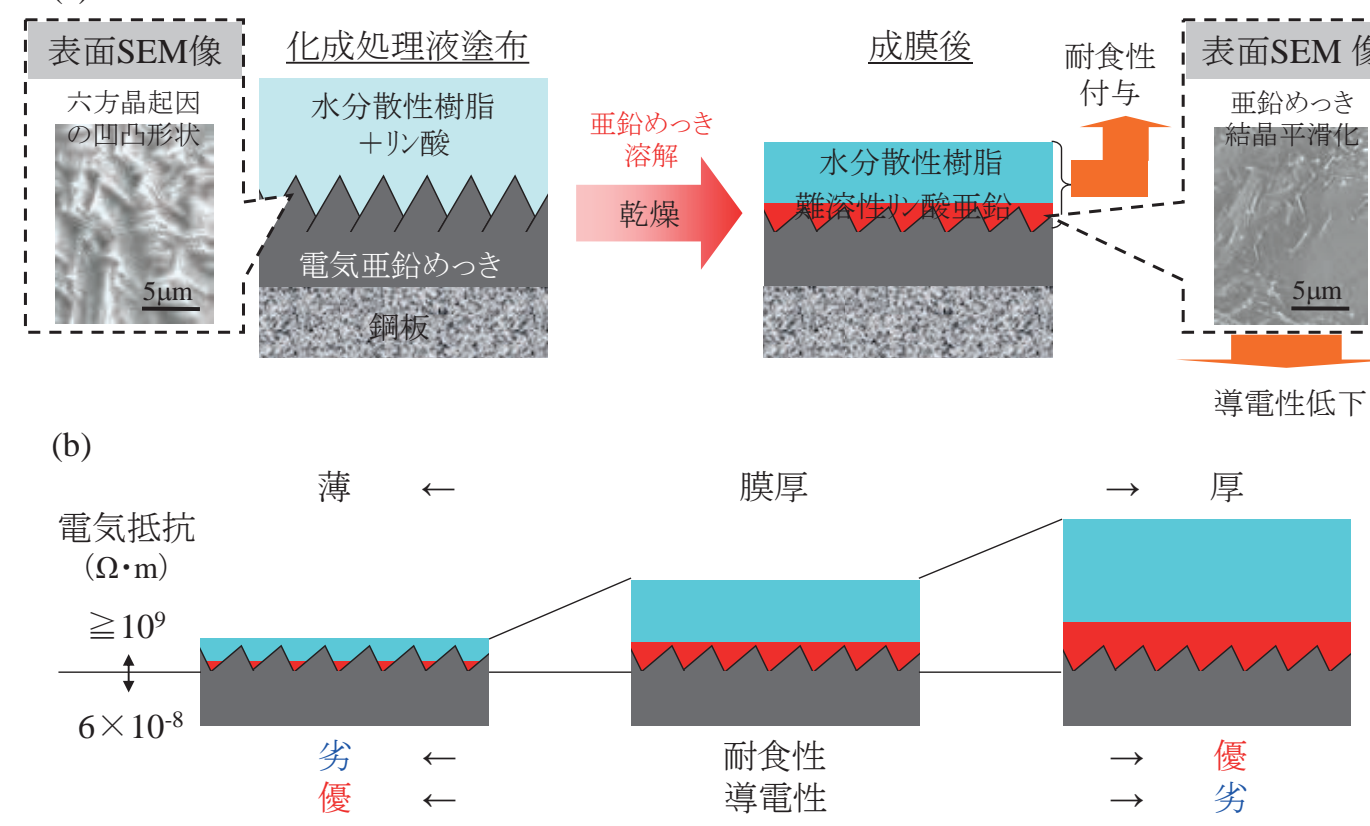

図 2 従来クロメート皮膜の特徵；(a) 反応層形成による亜鉛めっき結晶平滑化,(b) 化成皮膜厚が耐食性と導電性に及ぼす影響

小型モーターケースのプレス加工後の外観や熱交換機ろう付 け時の耐加熱変色性といった新しい機能に対するニーズも顕 在化し, 特殊用途に応じたクロメートフリー化成処理鋼板も 求められた。

\section{1 高機能化成処理鋼板}

有機樹脂とリン酸を複合した第一世代クロメートフリー皮 膜は，有機樹脂と難溶性リン酸亜鉛によるバリア性，密着性 および自己補修性を担保することで適度な耐食性を実現して いる ${ }^{14)}$ 。しかしながら, 図 2 (b)に示す通り耐食性と導電性 は二律背反の関係にあり，亜鉛めっき結晶の溶解反応も相 まって，耐食性を維持しながら導電性を向上させることは困 難であった。そこで松崎らは亜鉛めっき結晶凸部の形状を確 保しつつ, 有機樹脂と難溶性金属塩に相当するバリア層と密 着性を付与することが出来る皮膜成分を探索し，シリケート 化合物とナノサイズの微粒子シリカ (ナノシリカ) を複合化し た無機高分子皮膜を開発した（図 3)。この無機高分子皮膜の 塩水中における電気化学インピーダンス分光法(EIS)を測定 し, 皮膜抵抗 $\left(R_{\mathrm{c}}\right)$ と電荷移動抵抗值 $\left(R_{\mathrm{ct}}\right)$ を求めた。その結果, シリケート化合物の $R_{\mathrm{c}}, R_{\mathrm{ct}}$ はともに電気覀鉛めっきや有機 樹脂 / リン酸複合皮膜に比べて高かった。これは化成皮膜自 体のバリア性や亜鉛めっき表面と高密着性が発現したためと
考察している。また，ナノシリカを複合化することで $R_{\mathrm{c}}$, $R_{\mathrm{ct}}$ がさらに増加していることから, 三次元架橋構造により バリア性がさらに向上したと報告している ${ }^{6)}{ }^{18)}$ 。すなわち, この無機高分子皮膜は亜鉛めっきと共有結合するシリケート 化合物がナノシリカと緻密な三次元架橋構造を形成するため, (1) 酸成分と亜鉛めっきとの難溶性金属塩に代わる密着性に 優れた新規バリア層構築，（2）緻密性の高い三次元架橋を実 現した。その結果，優れたバリア性と密着性を担保しながら， 導通点となる電気亜鉛めっき結晶の凸部形状を維持すること に成功し，耐食性と導電性のバランスを向上させた (表 1)。

この無機高分子皮膜に表面自由エネルギーを最適化したウ レタン樹脂と潤滑剂を添加することで耐指紋性と潤滑性を付 与した高機能化成処理鋼板が開発された。主に AV・OA 機 器向けに耐食性と導電性を高度に両立する商品として量産化 されており ${ }^{19), 20)}$, 耐食性と導電性のバランスは海外材や従 来材よりも優れており，家電メーカーでは金属ガスケットの 削減に貢献している。

\section{2 多機能化成処理鋼板}

無機高分子皮膜に特殊エポキシ樹脂と形状保持型潤滑剂を 複合化することで粉体塗装性と高潤滑性を有す多機能化成処 理鋼板を開発し, 白物家電メーカーでの後塗装工程やプレス

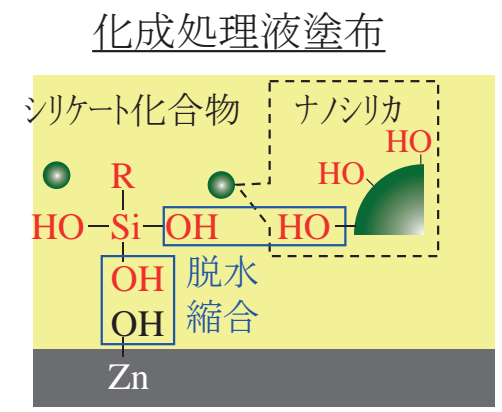

成膜後

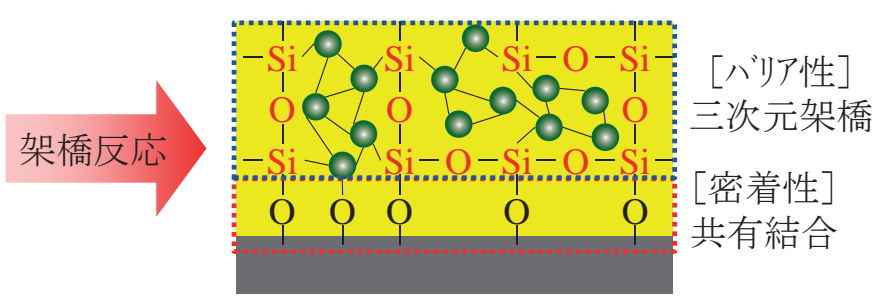

図 3 無機高分子皮膜の設計思想 
表 1 無機高分子皮膜の耐食性, 導電性と表面モフォロジー

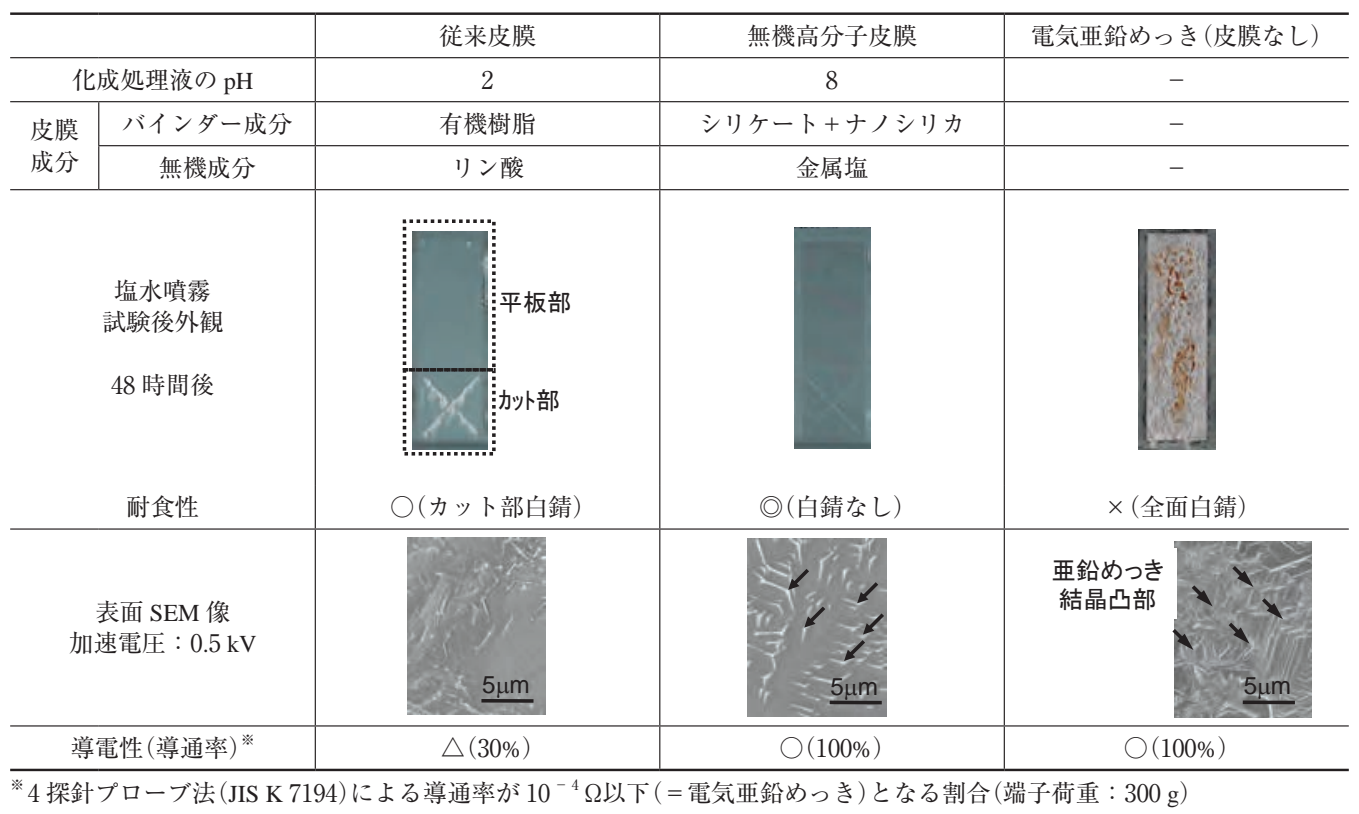

油塗布工程の省略が可能な商品が量産化されている ${ }^{15), 18), 21) 。 ~}$ 形状保持型潤滑剂は成膜後も球体形状を維持して化成皮膜表 面から突出するため, プレス金型との接触を軽減して優れた 潤滑性を実現している。従来は高耐食化成, 高潤滑化成, 粉 体塗装用化成など複数の少量製造品種が存在していたが，多 機能化成処理鋼板は全ての性能を兼ね備えているため, 鉄鋼 メーカーでの品種集約に成功し, 量産効果による製造コスト 低減を実現している。

\section{3 特殊用途化成処理鋼板}

車載小型モーターケースは, 多段のプレス機によって深絞 りやしごき等の厳しい加工が連続かつ高速で施されて成形さ れる。そのため, 成形品や金型の温度が著しく上昇し, 金型 と化成処理鋼板との摺動で皮膜が部分的に剥離しやすくなり， プレス後外観を損ねる。さらに, 皮膜の剥離カスはプレス油 に蓄積され, 以後のプレス成形材に再付着し, 成形後は脱脂 洗浄工程が必要となる。金藤ら ${ }^{22), 23)}$ は, 深絞りやしごき加 工性に悪影響を与える因子を調查し，プレス後表面の黒化は 有機樹脂とめっきのそれぞれの微細な剥離物とプレス油の混 合物であることを明らかにし，黒化の原因となる有機樹脂を 大幅に削減したクロメートフリー化成処理鋼板を開発し，ク ロメートと同等の加工後外観を実現した。また，亜鉛めっき と化成皮膜の密着性を適正化した上で薄膜化し, かつ剥離力 スが金型に再付着しない設計で，反応促進成分の低減に加え 防錆性も発現可能なシリカや無機成分を主体とするクロメー トフリー化成処理鋼板も開発されている ${ }^{24)}$ 。一方, 熱交換 器のろう付けなど鋼板が高温で加熱される場合には, めっき の形状変化と体積膨張に追従しきれず皮膜がひび割れを起こ し, 皮膜中の有機樹脂の変色も伴って外観が劣化する。藤林 らは無機高分子を形成する金属酸化物を活用した耐加熱変色 性に優れる化成処理鋼板を開発した ${ }^{25)}$ 。

\section{5. 次世代クロメートフリー皮膜の研究}

従来のクロメートフリー皮膜の自己補修性を担う無機系皮
膜成分は，湿潤環境下において溶出することで機能が発現さ れるが, 溶出量, 溶出期間ともに制御することが出来ないた め，長期的な防錆性能を付与するのは困難である。そこで, 防錆剤をマイクロカプセルなどのキャリアーに内包させ, 皮 膜中に分散させたオンデマンド防錆皮膜に関する研究に注目 が集まっている。内包された防錆剤はクラックなどの物理的 な欠陥, 光や湿度などの環境変化, $\mathrm{Cl}^{-} や \mathrm{pH}$ などの化学的 変化が生じた際に放出されるが, 外的な刺激が加わるまでは キャリアー中に保持されるため, 長期的な防錆が可能な次世 代クロメートフリー皮膜として期待されている。防錆剤を キャリアーに内包させる方法は大きく三つに分類され，層状 複水酸化物 $(\mathrm{LDH})$ の層間に防錆剂をインターカレートさせ る方法，孔質物質に防錆剂を担持させる方法，コア/シェル 構造を有するマイクロカプセルの中に防錆剂をカプセル化す る方法があり，様々な防錆剂を内包させたキャリアーが金属 材料の防錆皮膜成分として提案されている(表 2)。

$\mathrm{LDH}$ は腐食因子の $\mathrm{Cl}^{-}$などのアニオンが層間で交換反応 を起こすことにより防錆荗が放出されるものが多く,

Hayatdavoudi らはジンクリッチエポキシ樹脂にメルカプトベ ンゾチアゾール (MBT) をインターカレートさせた LDH を添 加し，鋼板の防錆皮膜として提案している ${ }^{28)}$ 。LDH を含ま ないジンクリッチエポキシ皮膜では亜鉛粒子のアノード反応 とともに $\mathrm{Cl}^{-}$の濃縮が起こり, 生成した $\mathrm{ZnCl}_{2}$ により水の加 水分解が促進されて $\mathrm{pH}$ が低下し, 覀鉛粒子の局部溶解が進 行する。一方, LDH を含むジンクリッチエポキシ皮膜では $\mathrm{Cl}^{-}$と $\mathrm{MBT}$ の交換反応が起こるために $\mathrm{ZnCl}_{2}$ の生成が抑制 され, 亜鉛粒子の犠牲防食作用が持続されるとともに, 放出 された MBT によって鋼板の腐食も抑制すると報告している。 孔質物質に防錆剂を担持させる方法には，金属酸化物粒子 や多孔質シリカなどの微粒子を用いるものと, ハロイサイト ナノチューブやセルロースナノファイバーを用いたものが提 案されている。矢吹らは亜硝酸カルシウムとセルロースナノ ファイバーをエポキシ樹脂中に分散させ, 鋼板の防錆皮膜と 
表 2 防錆剂をキャリアーに内包させたオンデマンド防錆皮膜の研究例

\begin{tabular}{|c|c|c|c|c|c|}
\hline キャリアー & 防錆剤 & トリガー & バインダー皮膜 & 塗装板 & 文献 \\
\hline \multirow{4}{*}{ LDH } & メルカプトベンゾチアゾール & $\mathrm{pH}, \mathrm{Cl}$ & エポキシ & 亜鉛めっき鋼板 & 26) \\
\hline & メルカプトベンゾチアゾール & $\mathrm{Cl}$ & エポキシ & 鋼板 & 27) \\
\hline & メルカプトベンゾチアゾール & $\mathrm{Cl}$ & ジンクリッチエポキシ & 鋼板 & 28) \\
\hline & バナジン酸 & $\mathrm{Cl}$ & エポキシ & アルミニウム板 & 29) \\
\hline \multirow{6}{*}{ 孔質物質 } & 8-ハイドロキノリン & スクラッチ & エポキシ & アルミニウム板 & 30) \\
\hline & セリウム & $\mathrm{pH}$ & エポキシ & アルミニウム板 & 31) \\
\hline & ベンゾトリアゾール & 光 & ゾルゲル & アルミニウム板 & 32) \\
\hline & セリウム & $\mathrm{pH}$ & シラン & 亜鉛めっき鋼板 & 33) \\
\hline & ベンゾトリアゾール & $\mathrm{pH}$ & ゾルゲル & アルミニウム板 & 34) \\
\hline & 亜硝酸カルシウム & スクラッチ & エポキシ & 鋼板 & 35) \\
\hline \multirow{5}{*}{ マイクロカプセル } & ポリシロキサン & スクラッチ & エポキシ & 鋼板 & 36) \\
\hline & シリルエステル & 湿度 & エポキシ & アルミニウム板 & 37) \\
\hline & アマニ油 & スクラッチ & ウレタン & 鋼板 & 38) \\
\hline & アミン化合物 & $\mathrm{pH}$ & ウレタン & 鋼板 & 39) \\
\hline & イソホロンジイソシアネート & スクラッチ & ウレタン & アルミニウム板 & 40) \\
\hline
\end{tabular}

して提案している ${ }^{35)}$ 。亜硝酸カルシウムとセルロースナノ ファイバーを分散させたエポキシ皮膜に人工欠陥を導入し, 塩水中の分極抵抗を測定したところ, 亜硝酸カルシウム単独 やセルロースナノファイバー単独添加のエポキシ皮膜または 添加剂なしのエポキシ皮膜に比べて抵抗值が高く, 亜硝酸力 ルシウムがセルロースナノファイバーに担持されたことでよ

り高い自己補修性が得られたと報告している(図 4)。

コア/シェル構造を有するマイクロカプセルは比較的合成 が容易であることやシェルを構成する樹脂種，コアとなる防 錆剂種の選択性が広い特徴を有する。千葉らはイソホロンジ イソシアネートと有機溶媒を内包するマイクロカプセルをウ レタン樹脂に分散させ，アルミニウム板上に塗布した被覆ア ルミニウム板を作製した。この被覆アルミニウム板に人工欠 陥を導入し, 温度 $20{ }^{\circ} \mathrm{C}$, 湿度約 $55 \%$ 環境下で $24 \mathrm{~h}$ 放置す ると欠陉部が被覆された(図 5)。この自己補修作用は有機溶 媒量に比例して効果が向上し, 内包された溶媒とともに溶出
したイソホロンジイソシアネートが空気中の水分と反応して ジアミン化合物を生成し, ジイソシアネートとジアミンの重

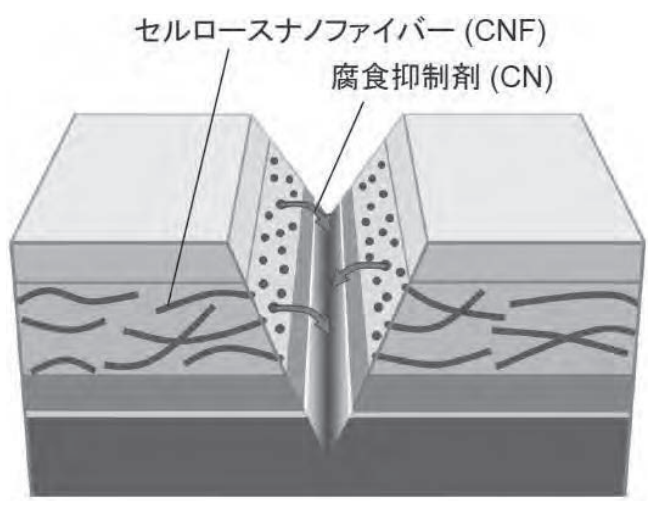

図 4 ナノファイバー含有エポキシ樹脂被覆鋼板の 自己補修メカニズム ${ }^{35)}$

(a)

20\% キシレン
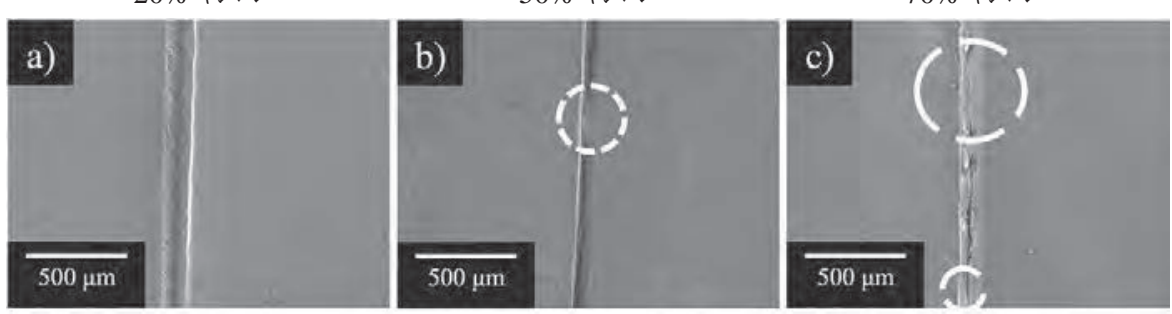

(b)
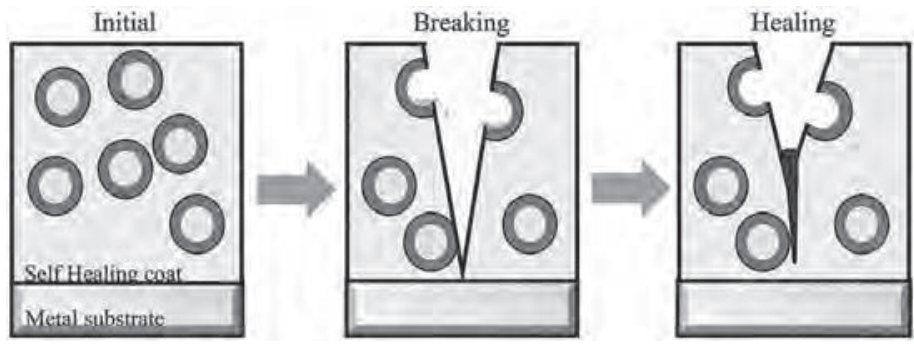

図 5 マイクロカプセル含有ウレタン樹脂被覆アルミニウム板 ${ }^{40)}$; (a) イソホロンジイソシアネート / キシレン溶液による人工欠楩部の修復, (b)マイクロカプセルによる自己補修メカニズム 
合によりポリウレア皮膜が形成したと考察している ${ }^{40)}$

\section{6.おわりに}

本報では 2000 年代前半までに開発された第一世代クロ メートフリー化成処理鋼板について, 皮膜設計の考え方と開 発動向を述べ，2000 年代半ば以降に開発された第二世代ク ロメートフリー化成処理鋼板の開発動向を紹介した。第一世 代クロメートフリー化成処理鋼板の開発においては, クロ メート皮膜の優れたバリア性, 密着性と自己補修性を実現す るための試行錯誤が行われ，主に有機無機複合皮膜によりク ロメートフリー化が達成された。その後, 家電製品の高機能 化, 海外材の台頭によるコスト競争, 特殊用途への適用など の社会的なニーズ変化に合わせた第二世代ロメートフリー化 成処理鋼板が開発され，特にバリア性と密着性に対する考え 方を深化させた皮膜開発が行われ, 高機能化, 多機能化を実 現している。今後は持続可能な社会の実現に向けて，防錆剤 をキャリアーに内包させたオンデマンド防錆皮膜が EoL 長 期化のための次世代クロメートフリー皮膜として期待される。

(Received August 16, 2019)

\section{文献}

1 ) 藤田 栄, 梶山浩志 ; 材料と環境, 50, 115 (2001).

2 ) 山下正明; 第 $167 \cdot 168$ 回西山記念技術講座, 日本鉄鋼協会編, 東京 ·神戸, 151 (1998).

3 ）須田 新, 萩野陸雄, 前田重義; 表面技術, 44, 841 (1993).

4 ）加藤千昭; 第 $186 \cdot 187$ 回西山記念技術講座, 日本鉄鋼協会編, 東京 ·神戸, 22 (2005)

5 ）吉見直人 ; 第 $223 \cdot 224$ 回西山記念技術講座, 日本鉄鋼協会編, 東京 ·大阪, (2015).

6 ）松崎 晃, 松田武士, 金子里江, 土本和明, 吉見直人 ; 表面技術, 70, 91 (2019).

7 ) S. R. White, N. R. Sottos, P. H. Geubelle, J. S. Moore, M. R. Kessler, S. R. Sriram, E. N. Brown, S. Viswanathan ; Nature, 409, 794 (2001).

8 ）梅田昭三 ; 実務表面技術, 26, 257 (1979).

9 ) 中元忠繁; 環境研究, 155, 18 (2009).

10）久保裕治, 半谷公司, 児玉真二 ; 新日鉄技報, 391, 48 (2011).

11）吉見直人, 松崎 晃, 安藤 聡, 窪田隆広, 山下正明 ; 鉄と鋼, 89 , 80 (2003).

12) K. Aramaki ; ibit., 47, 1285 (2005).

13）鈴木優貴, 森下敦司 ; 表面技術協会第125回講演大会要旨集, 174 (2012).

14）野呂寿人，岡井和久，松崎 晃，吉見直人；CAMP-ISIJ，20,539 (2007)
15）松田武士, 松崎 晃, 杉本芳春; JFE技報, 30, 43 （2012）.

16）金子里江, 渡辺裕一, 多田千代子, 安藤 聡, 中丸裕樹 ; CAMPISIJ, 23, 429 (2010).

17）金子里江, 渡辺裕一, 多田千代子, 安藤 聡, 中丸裕樹 ; 表面技術, 67, 557 (2016).

18) T. Matsuda, A. Matsuzaki, K. Tsuchimoto, Y. Sugimoto ; Proc. 9th. Int. Conf. on Zinc and Zinc Alloy Coated Steel Sheet, 583 (2013).

19）土本和明, 松田武士, 松崎 晃; JFE技報, 41, 73 （2018）。

20) K. Tsuchimoto, T. Matsuda, A. Matsuzaki, N. Yoshimi ; Proc. 10th. Int. Conf. on Zinc and Zinc Alloy Coated Steel Sheet, 216 (2015).

21) T. Matsuda, A. Matsuzaki, K. Tsuchimoto, N. Yoshimi ; Proc. Asia Steel Int. Conf., 120 (2015).

22）金藤泰平, 菊池郁夫, 森下敦司, 山口伸一, 森陽一郎, 山岡育郎, 新 頭英俊 ; 表面技術協会第117回講演大会要旨集, 212 (2008).

23) T. Kaneto, I. Kikuchi, A. Morishita, S. Yamaguchi ; Proc. 7th. Int. Conf. on Zinc and Zinc Alloy Coated Steel Sheet, 780 (2007).

24）JFE技報; 30, 59 (2012).

25）藤林亘江, 松崎 晃, 杉本芳春; JFE技報, 30, 38 (2012).

26) M. F. Montemor, D. V. Snihirova, M. G. Taryba, S. V. Lamaka, I. A. Kartsonakis, A. C. Balaskas, G. C. Kordas, J. Tedim, A. Kuznetsova, M. L. Zheludkevich, M. G. S. Ferreira ; Electrochim. Acta, 60, 31 (2012).

27) Y. Dong, F. Wang, Q. Zhou ; J. Coat. Technol. Res., 11, 793 (2014).

28) H. Hayatdavoudi, M. Rahsepar ; J. Alloy. Compd., 711, 560 (2017).

29) M. L. Zheludkevich, S. K. Poznyak, L. M. Rodrigues, D. Raps, T. Hack, L. F. Dick, T. Nunes, M. G. S. Ferreira ; Corr. Sci., 52, 602 (2010).

30) A. C. Balaskas, I. A. Kartsonakis, L. A. Tziveleka, G. C. Kordas ; Prog. Org. Coat., 74, 418 (2012).

31) D. Snihirova, S. V. Lamaka, M. F. Montemor ; Electrochim. Acta, 83, 439 (2012).

32) V. Skorb, D. G. Shchukin, H. Möhwald, D. V. Sviridov ; J. Mater. Chem., 19, 4931 (2009).

33) M. F. Montemor, M. G. S. Ferreira ; Prog. Org. Coat., 63, 330 (2008).

34) G. L. Li, Z. Zheng, H. Möhwald, D. G. Shchukin ; ACS Nano, 7, 2470 (2013).

35）矢吹彰広 ; 表面技術, 65, 470 (2014).

36) S. H. Cho, S. R. White, P. V. Braun ; Adv. Mater., 21, 645 (2009).

37) S. J. García, H. R. Fischer, P. A. White, J. Mardel, Y. González-García, J. M. C. Mol, A. E. Hughes ; Prog. Org. Coat., 70, 142 (2011).

38) P. D. Tatiya, R. K. Hedaoo, P. P. Mahulikar, V. V. Gite ; Ind. Eng. Chem. Res., 52, 1562 (2013).

39) H. Choi, K. Y. Kim, J. M. Park ; Prog. Org. Coat., 76, 1316 (2013).

40) M. Chiba, K. Anetai, C. Yamada, S. Pletincx, H. Verbruggen, A. Hyono, I. De Graeve, H. Terryn, H. Takahashi ; ECS Transactions, 75, 89 (2017). 